\title{
Effect of Protease Treatment on the Physical Properties and Dyeability of Wool/Nylon Blend to Cutch Natural Dye
}

\author{
Waly A. I. ${ }^{1}$, Marie M. M. ${ }^{2}$, Shahin M. F. ${ }^{3}$, Faroun N. M. S. ${ }^{4}$ \\ ${ }^{1}$ Textile Research Division, National Research Center, Cairo, Egypt \\ 2,3,4 Textile Printing, Dyeing and Finishing Department, Faculty of Applied Arts, Helwan University, Cairo, Egypt
}

\begin{abstract}
The effect of protease enzyme treatment on the morphological structure, wettability and dyeability of wool/nylon blended fabric was studied. The enzymatic treatment and dyeing with cutch (Acacia catechu) natural dye was carried out by two different methods, i.e. one-bath two-stages and two- bath processes for comparison. The effect of enzyme concentration, treatment time and surfactant concentration on the dyeing properties were investigated. This study confirms surface modification of wool and nylon fibers in their blend as a result of protease treatment, by measurements of dyeability (K/S), surface properties (SEM), wettability and fastness properties. Colour strength of dyed fabrics with cutch dye showed higher values on enzyme treated samples compared to the untreated fabrics. The results of K/S obtained with the two-bath method were better than that obtained with the one- bath method. The fastness properties to washing, perspiration and light were measured according to standard methods. In general the fastness properties were found to be ranged from good to very good.
\end{abstract}

Keywords: Wool/nylon, cutch, natural dye, enzymatic treatment, dyeing, protease

\section{Introduction}

Green chemistry using biotechnology has joined incredible importance in the textile wet processing industry. The search for new, efficient and eco-friendly alternatives have increased interest in using green catalysts i.e., enzymes. (1)

During the last two decades, a large amount of information has been accumulated concerning the enzyme treatment of fibers under various conditions. The advantages offered by biotechnology have led to profound modifications being introduced to almost all of the chemical finishing stages. (2)

In recent times, enzymes have received widespread attention in various textile processes with a view to making them ecofriendly and less toxic. (3), which ranged from desizing of cotton fabrics, polishing of wool cuticle surface, degumming of silk fabrics, activated peroxide bleaching, scouring aid in laundry of worsted garments and also in decolorization of dye house wastewaters. (4) Enzymes can also be used as a pretreatment on dyed wool fabrics to improve softness, handle, drape, pilling resistance and change the colour. (5)

Enzymatic processing was first proposed and introduced as a biotechnology option because it is compatible with existing equipment and hence can be expected to have reduced costs, energy requirements, and water pollution. Enzymatic processing does not cause environmental pollution, and it is beneficial to the fiber because it minimizes fiber damage. (6)

Also enzymes are gaining an increasing role in textile wet processing due to their proven flexibility, reliability, and concerns about safety, energy and water conservation, and environmental responsibility. (7)

Enzymes are natural protein molecules that act as highly efficient catalysts in biochemical reactions, i.e., they help a chemical reaction to take place quickly and efficiently. This catalytic capability is what makes enzymes unique. Enzymes not only work efficiently and rapidly, but they are also biodegradable. (8) However, they are $\mathrm{pH}$, time, temperature and substrate specific and can be applied potentially to all stages of textile production. (5)

The enzymatic treatment of textiles significantly improves some of their properties as well as increases their aesthetic values and comfort of use. Modification of fabric improves dyeability but the discharge of toxic, non -biodegradable substances as effluent pollute the environment and it is becoming a serious concern for textile industries. $(7,9)$

Commercial sources of enzymes are obtained from any biological source _ animal, plants and microbes. (10)

Developments in genetic engineering bring about improvements in the stability, specificity, economy as well as overall application potential of industrial enzymes in textile finishing. (1)

Wool/polyamide is a very popular blend for woven apparel and carpets. It can show the complementary properties compared to pure polyamide or wool fibers in terms of crease recovery, durability, abrasion resistance, fast drying, and dimensional stability. (11)

Pre-treatment of wool fiber with enzyme leads to increase its hydrophilicity with enhanced swelling properties.

The wool fibre surface is covered by a covalently-bonded fatty layer, being responsible for the hydrophobicity of wool. (12) As for the enzymatic hydrolysis of synthetic fibers, it is done to improve some of their undesired properties such as hydrophobicity, low dyeability, and insufficient washability. (13)

Among different hydrolytic enzymes, proteases have been reported to hydrolyse wool and polyamide. Proteases 


\section{International Journal of Science and Research (IJSR) \\ ISSN (Online): 2319-7064}

Index Copernicus Value (2013): 6.14 | Impact Factor (2014): 5.611

constitute the most important group of industrial enzymes which major application is the detergent industry. $(5,14)$

Protease can catalyse the degradation of different component of wool fibre. (12) Protease enzyme penetrates into amorphous region and causes swelling and it leads to changes in the disulphide region of cystine than amide components during chemical degradation. (5)

The hydroscopicity of polyamide (nylon) is low and approaches greatly to that of cell. acetate. The absence of swelling greatly hinders the penetration of dyes into nylon fiber. In chemical structure nylon resembles most closely the protein fiber particularly silk but contains fewer basic groups than the later. The polar groups contained in nylon fiber are predominantly amide (-CONH-) groups and the number of strongly hydrophilic groups is very limited, resulting in small swelling properties of fibers. Although alkaline hydrolysis is an effective way to improve fiber wettability, this treatment is difficult to control and severe damage of fiber can be obtained. Recently it was reported that surface modification of nylon fibers could be achieved with hydrolytic enzymes, such as proteases which was reported to hydrolyse polyamide. (14)

Environmental issues in the production and application of synthetic dyes once again revived consumer interest in natural dyes during the last decades of the twentieth century. Textiles colored with natural dyes are preferred by environmentally conscious consumers and today there is a niche market for such textiles. (15)

Recently, most of the commercial dyers and textile export houses have started re-looking to the maximum possibilities of using natural dyes for dyeing and printing of different textiles for targeting niche market. Natural dyes produce very uncommon, soothing and soft shades as compared to synthetic dyes. On the other hand, synthetic dyes, which are widely available at an economical price and produce a wide variety of colours, sometimes causes skin allergy and other harmfulness to human body, produces toxicity/chemical hazards during its synthesis, releases undesirable/hazardous/toxic chemicals etc.

For successful commercial use of natural dyes for any particular fibres, the appropriate and standardized techniques for dyeing for that particular fibre-natural dye system need to be adopted. Therefore to obtain newer shade with acceptable colour fastness behaviour and reproducible colour yield, appropriate scientific dyeing techniques/procedures are to be derived. (16)

In this study, wool/nylon, wool and nylon fabrics were treated with protease enzyme to investigate the effects of fiber surface modification on the physical properties and the dyeabilities of the different fabrics to cutch natural dye.

\section{Experimental}

\subsection{Materials}

\subsubsection{Fabric}

Three different types of knitted fabrics were used throughout this work, namely: $100 \%$ wool fabric with weight 180 $\mathrm{gm} / \mathrm{m} 2,100 \%$ nylon (poly-amide) fabric with weight 140 $\mathrm{gm} / \mathrm{m} 2$ and $50 / 50 \%$ blend fabric (wool/nylon) with weight $165 \mathrm{gm} / \mathrm{m} 2$. These fabrics were received from Delta Textile Egypt Company, Cairo, Egypt.

\subsubsection{Dyes}

Cutch natural dye from "Table rock Llamas Fiber Arts Studio, Inc.", Colorado, USA, was used in this study. Cutch/Catechu/Katha (Botanical name: Acacia catechu) is a brown natural dye obtained chiefly from the heartwood of Acacia catechu, found in most of the Indian sub-Himalayas. The chief colouring component present in the cutch is catechin having molecular formula $\mathrm{C}_{15} \mathrm{H}_{14} \mathrm{O}_{6}$. (17)<smiles>Oc1cc(O)c2c(c1)O[C@H](c1ccc(O)c(O)c1)[C@H](O)C2</smiles>

\subsubsection{Chemicals and Auxiliaries}

Protease enzyme - TRANS CHEM., Egypt. Acetic Acid, Hydrochloric Acid and Sodium Carbonate of laboratory grade were used.

Non-ionic detergent (Chromatech 3.Q.J) supplied by Chromatech Co., England and dispersing agent (Ebcasperse), and a non-ionic wetting agent EBCA wet LF supplied by Egyptian British Co., Egypt were also used.

Ferrous sulphate $\left(\mathrm{FeSO}_{4} .7 \mathrm{H}_{2} \mathrm{O}\right)$ was used as a mordant throughout this study.

\subsection{Methods}

\subsubsection{Protease enzymatic treatment}

\subsubsection{One bath enzymatic treatment and dyeing}

The three kinds of fabrics were bio-treated with the enzyme at L.R 1:50, and at different concentrations of the enzyme ranging from 0.5 to $3 \mathrm{gm} / \mathrm{L}$. The process was carried out at $\mathrm{pH}=8$ and at $50^{\circ} \mathrm{C}$, using $4 \%$ dye (o.w.f) and $2 \mathrm{gm} / \mathrm{L}$ dispersing agent in the bath.

The treatment process was carried out for different durations ranging from 30-60 min. Also the addition of a non-ionic wetting agent was studied; it was added at different concentrations i.e. $(0,0.5,1,1.5$, and 2$) \mathrm{gm} / \mathrm{L}$.

At the end of treatment time, the temperature was raised to $90^{\circ} \mathrm{C}$ and dyeing process is taking place for 60 minutes, then $5 \mathrm{gm} / \mathrm{L}$ of ferrous sulphate (mordant) was added and the 


\section{International Journal of Science and Research (IJSR) \\ ISSN (Online): 2319-7064 \\ Index Copernicus Value (2013): 6.14 | Impact Factor (2014): 5.611}

process was continued for another 30 minutes. Then washing process was performed with $2 \mathrm{gm} / \mathrm{L}$ non-ionic detergent at $50^{\circ} \mathrm{C}$ for 15 minutes.

\subsubsection{Two- bath (enzymatic treatment then dyeing):}

The same conditions and concentrations of materials which were used in the one-bath method were applied in two different baths. Wool, nylon and wool/nylon blended fabrics were bio-treated first in a bath containing the enzyme, at different concentrations as mentioned earlier in the one bath method with non ionic wetting agent at different concentrations, the process was performed at $\mathrm{pH}=8$ and at $50^{\circ} \mathrm{C}$ for different durations and at L.R. 1:50.

Then the pretreated samples were rinsed with cold water and then with hot water at $85^{\circ} \mathrm{C}$ for 15 minutes to denature the enzyme. Finally the samples were rinsed with cold water and air- dried.
After which the samples were dyed with cutch natural dye in a separate bath at L.R 1:50 with $4 \%$ dye and $2 \mathrm{gm} / \mathrm{L}$ dispersing agent. The bath was set at $50^{\circ} \mathrm{C}$ then the temperature was raised to $90^{\circ} \mathrm{C}$ during $15 \mathrm{~min}$. and the dyeing process proceed for further 60 minutes, after which the mordant was added to the same bath at different concentrations $(5-10 \mathrm{gm} / \mathrm{L})$ and the process was continued for another 30 minutes at $90{ }^{\circ} \mathrm{C}$. Then the washing process was performed as mentioned before.

\subsubsection{Dyeing with cutch natural dye}

The dyeing processes i.e., one-bath two stages method and two-bath method are illustrated in Fig. (1) and (2) respectively.

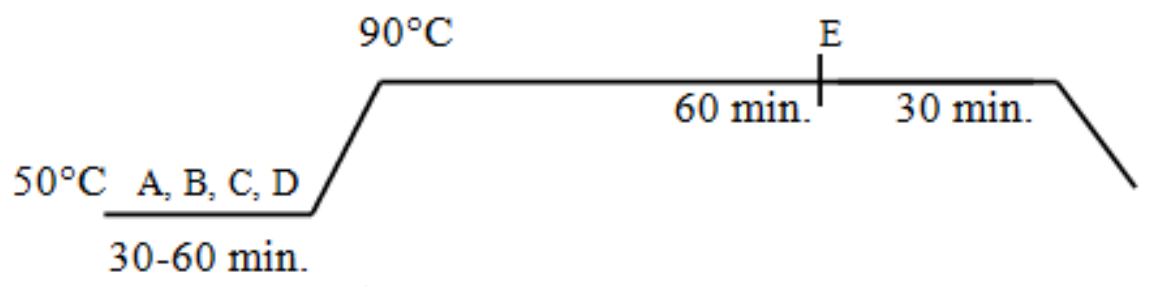

(One-bath two stages method)

Figure 1: enzymatic treatment (A) protease, (B) cutch dye, (C) Ebcawet a non- ionic wetting, (D) Ebcasperse a dispersing agent, (E) mordant $\mathrm{Fe} \mathrm{SO}_{4}$.

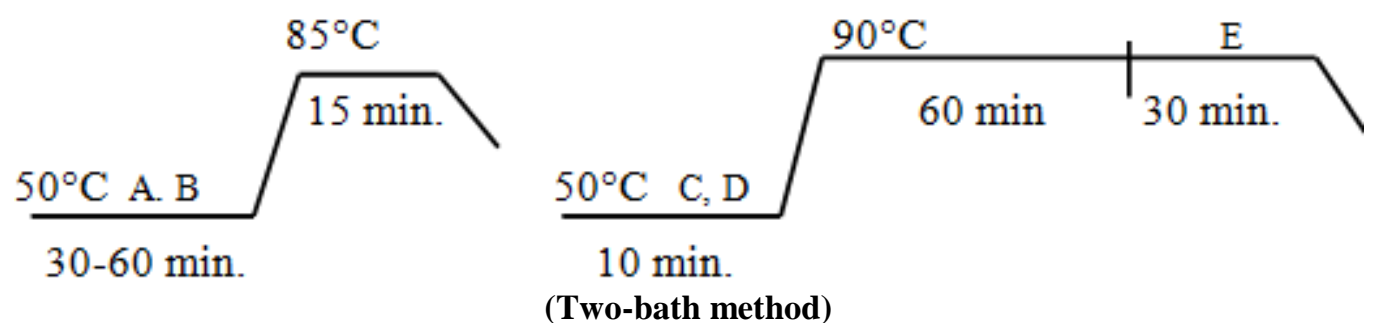

Figure 2: (A) protease enzyme, (B) Ebcawet a non-ionic wetting, (C) Ebcasperse a dispersing agent, (D) cutch dye, (E) mordant $\mathrm{Fe} \mathrm{SO}_{4}$.

\subsection{Measurements and testing}

\subsubsection{Colour measurements}

The dyed samples were subjected to colour measurement by using reflection spectrophotometer model Optimatch 3100, SDL Company, England. The K/S values were obtained directly according to Kubelka Munk equation:

$$
\mathrm{K} / \mathrm{S}=(1-\mathrm{R})^{2} / 2 \mathrm{R}
$$

Where $\mathrm{K}$ and $\mathrm{S}$ are the absorption and scattering coefficient respectively, and $\mathrm{R}$ is the reflectance of the dyed fabric.

\subsubsection{Determination of the wettability}

A standard method for measuring wettability was used (AATCC test method 39-1980) to determine the wettability of the wool/nylon blend samples treated with protease enzyme compared to untreated samples.

\subsubsection{Scanning electron microscope (SEM)}

The surface of fiber samples of protease treated and untreated fabrics were investigated using a scanning electron microscope $(\mathrm{JE} 100 \mathrm{~s})$, at magnification $=6000 \mathrm{x}$.

\subsubsection{Colour fastness}

Fastness properties of the dyed fabrics and mordanted with ferrous sulphate were evaluated according to ISO standard methods. The specific tests were: colour fastness to domestic and commercial laundering: ISO 105-C02 and colour fastness to perspiration: ISO 105-E04. The samples were also subjected to light fastness standard test (Xenon Lamp), according to ISO test method: ISO 105-B02.

\section{Results and Discussion}

The bio-treatment of nylon, wool and wool/nylon blend fabrics and dyeing with cutch natural dye took place according to two different methods i.e. (one- bath two stages and two- bath enzymatic treatment and dyeing processes), in order to compare the two methods and figure out the most suitable method to apply the protease enzyme on the fabrics and to achieve maximum colour strength as well when dyeing with cutch natural dye.

Protease is a class of enzymes, that actives only on protein macromolecules and its activity begins with hydrolysis of 


\section{International Journal of Science and Research (IJSR) \\ ISSN (Online): 2319-7064}

Index Copernicus Value (2013): 6.14 | Impact Factor (2014): 5.611

the covalent peptide bonds that link successive amino acid residues in a polypeptide chains and this process is termed proteolysis. The initial products of proteolytic process are amino acids and small peptides. The protease will cause the cleavage of a peptide link as follows:

$$
\mathrm{R}_{1}-\mathrm{CO}-\mathrm{NH}-\mathrm{R}_{2}+\mathrm{H}_{2} \mathrm{O} \longrightarrow \mathrm{R}_{1}-\mathrm{COO}^{-}+{ }^{+} \mathrm{NH}_{3}-\mathrm{R}_{2}
$$

As for polyamide fibres, many previous studies indicated that dyeability, hydrophilicity and fastness properties of polyamide fibers can be improved by protease and lipase enzymes. $(13,4)$ The Hydrolytic enzymes have potential to modify the PA polymer surfaces (18), as it has been shown in the SEM images for protease treated fibre, which indicate the surface modification of the fiber in comparison with untreated fiber. Also for the enzyme-treated samples, it is possible to increase the ionic and hydrogen bonds in amorphous or less-ordered (paracrystalline) regions. (13) According to the previous, it is expected to treat wool/polyamide blended fabric with protease enzyme successfully in order to enhance its dyeability towards cutch dye achieving maximum colour strength.

\subsection{Effect of Enzyme Concentration}

Three kinds of fabrics i.e. wool/nylon blend, wool and nylon were subjected to a bio-treatment by using protease enzyme at different concentrations, in order to study its effect on the dyeability of the fabrics to cutch dye.

The colour strengths of the blend dyed samples for the two methods were measured and the results are illustrated in figure (3) and table (1).

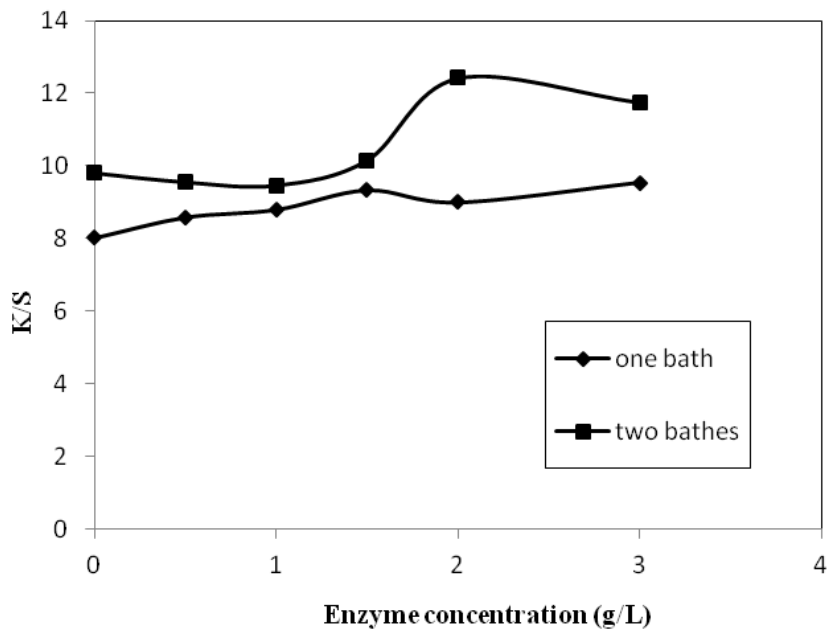

Figure 3: Effect of enzyme concentration on the colour strength of wool/nylon blended fabrics dyed with cutch natural dye.

It was concluded from fig. (3) that the colour strength increased as a result of increasing enzyme concentration to reach its maximum value at $3 \mathrm{gm} / \mathrm{L}$ in case of one- bath method and $2 \mathrm{gm} / \mathrm{L}$ for two- bath method. As for the colour strength of wool and nylon dyed fabrics, the results are plotted in table (1):
Table 1: The relationship between the enzyme concentration and the $\mathrm{K} / \mathrm{S}$ of the enzyme treated wool and nylon fabrics dyed with cutch natural dye

\begin{tabular}{|c|c|c|c|c|}
\hline \multirow{2}{*}{$\begin{array}{c}\text { Enzyme } \\
\text { Conc. }\end{array}$} & \multicolumn{2}{|c|}{ One- bath method } & \multicolumn{2}{c|}{ Two- bath method } \\
\cline { 2 - 5 } & $\begin{array}{c}\text { Wool } \\
100 \%\end{array}$ & $\begin{array}{c}\text { Nylon } \\
100 \%\end{array}$ & $\begin{array}{c}\text { Wool } \\
100 \%\end{array}$ & $\begin{array}{c}\text { Nylon } \\
100 \%\end{array}$ \\
\hline $0.0 \mathrm{~g} / 1$ & 13.90 & 3.10 & 16.45 & 3.46 \\
\hline $0.5 \mathrm{~g} / 1$ & 15.21 & 2.88 & 16.3 & 3.33 \\
\hline $1.0 \mathrm{~g} / 1$ & 13.75 & 2.75 & 15.92 & 3.73 \\
\hline $1.5 \mathrm{~g} / 1$ & 12.68 & 3.11 & 16.4 & 3.43 \\
\hline $2.0 \mathrm{~g} / 1$ & 13.07 & 2.81 & 17.4 & 4.02 \\
\hline $3.0 \mathrm{~g} / 1$ & 13.2 & 3.27 & 17.87 & 4.12 \\
\hline
\end{tabular}

From table (1), it can be noticed that in the one bath method the maximum increase in $\mathrm{K} / \mathrm{S}$ for wool fibers was at $0.5 \mathrm{gm} / \mathrm{L}$ enzyme, after which the $\mathrm{K} / \mathrm{S}$ was decreased as the concentration of enzyme increased, but as for nylon fibers, there was no great change in the colour strength. In case of two- bath method, the maximum colour strength for wool and nylon fibers was achieved at $3 \mathrm{gm} / \mathrm{L}$.

Also it is important to mention that the two- bath method in general gives better results than the one bath method, this could be due to the presence of the dye and the enzyme in one bath. In the one- bath method the dyeing stage is carried out at $90^{\circ} \mathrm{C}$, at this high temperature the enzyme protein is transformed from globular to random coil form and denatured. Under this condition the hydrophobic dyeenzyme interactions increases. The denatured enzyme precipitates; bind dye from the dye solution leading to decrease its concentration. Thus, the amount of adsorbed dye on fiber surface decreases giving lowest colour strength. (19)

\subsection{Effect of treatment durations}

The importance of this factor and its impact on the efficiency of the enzymatic treatment and hence the colour strength of the dyed fabrics with cutch natural dye was studied in details. The colour strength of the blend dyed samples for the two methods was measured and the results are shown in figure (4) and table (2).

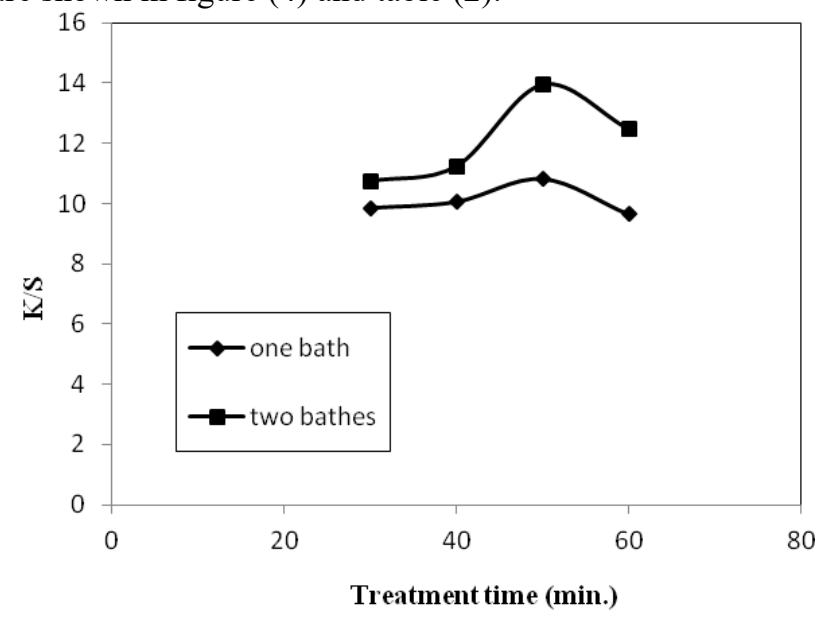

Figure 4: Effect of treatment time on the colour strength of wool/nylon blended fabrics dyed with cutch natural dye

From figure (4), it is well observed that the colour strength of the dyed samples increases by increasing the treatment time, and it reaches its maximum value when performing the 


\section{International Journal of Science and Research (IJSR) \\ ISSN (Online): 2319-7064}

Index Copernicus Value (2013): 6.14 | Impact Factor (2014): 5.611

enzymatic treatment for 50 minutes, after which there is a slight decrease. It is clear that prolonged time, gives the enzyme the opportunity to do its action on the fibers, resulting in higher colour strength. In general, it is clearly noticed, from table (2) that the colour strengths on both wool and nylon fabrics are higher when using the two-bath method compared to the one-bath. As for the colour strength of wool and nylon dyed fabrics, the results are illustrated in table (2):

Table 2: The relationship between the treatment time and the K/S of the enzyme treated wool and nylon fabrics dyed with cutch natural dye

\begin{tabular}{|c|c|c|c|c|}
\hline \multirow{2}{*}{$\begin{array}{c}\text { Treatment } \\
\text { Time (min.) }\end{array}$} & $\begin{array}{c}\text { One- bath method } \\
\text { Wool } \\
100 \%\end{array}$ & $\begin{array}{c}\text { Nylon } \\
100 \%\end{array}$ & $\begin{array}{c}\text { Wool } \\
100 \%\end{array}$ & $\begin{array}{c}\text { Nylon } \\
100 \%\end{array}$ \\
\hline 30 min. & 13.53 & 3.38 & 16.38 & 3.41 \\
\hline 40 min. & 17.82 & 3.13 & 20.20 & 3.65 \\
\hline 50 min. & 18.63 & 3.27 & 19.80 & 3.47 \\
\hline 60 min. & 16.78 & 2.95 & 18.71 & 3.50 \\
\hline
\end{tabular}

It may be concluded from table (2) that as for wool fibers in a one bath method, the best K/S (18.63) was achieved when performing the bio- treatment for 50 minutes, but as for the two- bath method performing the pretreatment process for 40 minutes was better $(\mathrm{K} / \mathrm{S}=20.20)$. It is also obvious that there is no much change in the colour strength for nylon fibers for both methods; the essential action of the enzyme was on wool fibers.

\subsection{Effect of wetting agent concentration}

The effect of the addition of non-ionic wetting agent to one bath and two- bath bio-treatment and dyeing processes was investigated in details in order to determine the role of adding this surfactant to the bath and how much it can affect the obtained K/S of the dyed fabrics with cutch natural dye.

The colour strength of the blend dyed samples for the two methods was measured and the results are plotted in figure (5).

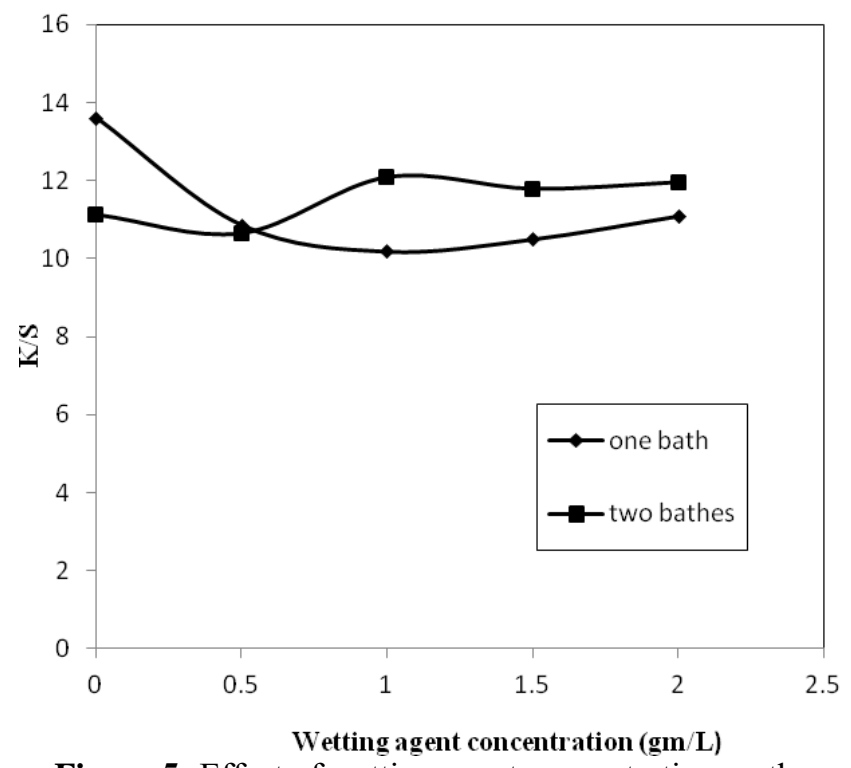

Figure 5: Effect of wetting agent concentration on the colour strength of wool/nylon blended fabrics dyed with cutch natural dye.
The action of surfactant on the efficiency of the used processes for attaining highest colour strengths on the wool and nylon fabrics is illustrated in table (3):

Table 3: The relationship between the wetting agent concn. and the $\mathrm{K} / \mathrm{S}$ of the enzyme treated wool and nylon fabrics dyed with cutch natural dye

\begin{tabular}{|c|c|c|c|c|}
\hline \multirow{2}{*}{$\begin{array}{c}\text { Wetting agent } \\
\text { conc. (gm/L) }\end{array}$} & \multicolumn{2}{|c|}{ One- bath method } & \multicolumn{2}{c|}{ Two- bath method } \\
\cline { 2 - 5 } & $\begin{array}{c}\text { Wool } \\
100 \%\end{array}$ & $\begin{array}{c}\text { Nylon } \\
100 \%\end{array}$ & $\begin{array}{c}\text { Wool } \\
100 \%\end{array}$ & $\begin{array}{c}\text { Nylon } \\
100 \%\end{array}$ \\
\hline $0 \mathrm{gm} / \mathrm{L}$ & 22.13 & 3.70 & 20.20 & 3.65 \\
\hline $0.5 \mathrm{gm} / \mathrm{L}$ & 20.41 & 3.53 & 20.42 & 2.92 \\
\hline $1 \mathrm{gm} / \mathrm{L}$ & 19.40 & 3.22 & 21.14 & 2.9 \\
\hline $1.5 \mathrm{gm} / \mathrm{L}$ & 18.76 & 3.22 & 18.77 & 3.12 \\
\hline $2 \mathrm{gm} / \mathrm{L}$ & 17.87 & 3.31 & 23.78 & 2.84 \\
\hline
\end{tabular}

It is noticeable from the previous results shown in fig. (5) and table (3), that addition of wetting agent in one- bath dyeing method decreases the dye uptake on the two fabrics, on contrast, in the two- bath method, the dye uptake on wool increased gradually with increasing the concentration of the wetting agent till reaching $2 \mathrm{gm} / \mathrm{L}$.

These are expected results since lot of researches indicate that non-ionic surfactants retard the sorption processes of dye from the dyeing bath, as non-ionic surfactants in dyeing baths affect the physical and chemical properties of dye solutions, inducing the decomposition of aggregates and agglomerates and thereby resulting in the formation of surfactant-dye complexes. $(20,21)$

Some other researches clarified strong interaction between the natural dyes and the surfactants. The results indicate (surfactant- dye) complex formation and domination of adsorption in comparison to micellization. $(22,23)$

On the other hand, when separating the enzymatic treatment and the dyeing processes into two bathes, the colour strength of the dyed fabrics namely (wool and wool/nylon) increased while there is no much difference for the nylon fabrics. This is due to separating the surfactant from the dye in two different baths as explained before. Also some researches indicate the help of the surfactant to the enzyme action on the fabric resulting of higher colour strength gained as shown in the two- bath method.

The interaction between surfactants and enzymes improves enzyme stability and activity, and, therefore, the efficiency of enzymatic hydrolysis of fibers is enhanced. (24)

\subsection{Scanning Electron Microscopy (SEM)}

The SEM images of wool, nylon and their blend fabrics before and after enzymatic treatment with $2 \mathrm{gm} / \mathrm{L}$ protease are shown in figure (6). It was observed from figure (6), that there is some damage in the outer hydrophobic layer on both wool and nylon and thereby their blend which may be attributed to the hydrolysis reaction of protease, resulting in an enhanced dyeability and wettability of both wool and nylon and thus the blend fabric. 


\section{International Journal of Science and Research (IJSR) \\ ISSN (Online): 2319-7064 \\ Index Copernicus Value (2013): 6.14 | Impact Factor (2014): 5.611}

The image of untreated wool (Fig.6a) shows the appearance of the epicuticle layer in a sharp form while after protease treatment the sharpness was relatively lower (Fig.6b). The SEM image of untreated nylon (Fig.6e) indicates that nylon has relatively smooth surface on contrast to the treated nylon

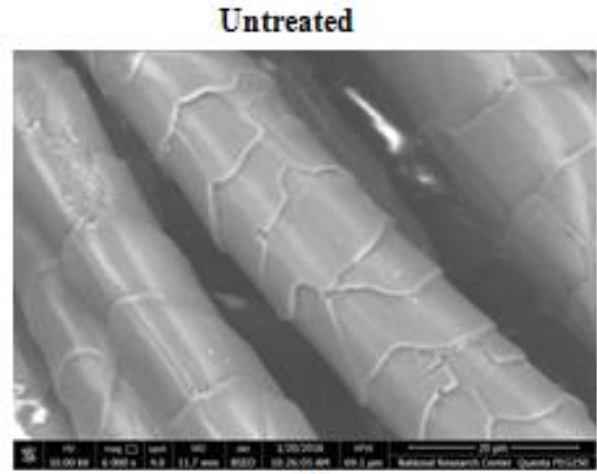

(a)

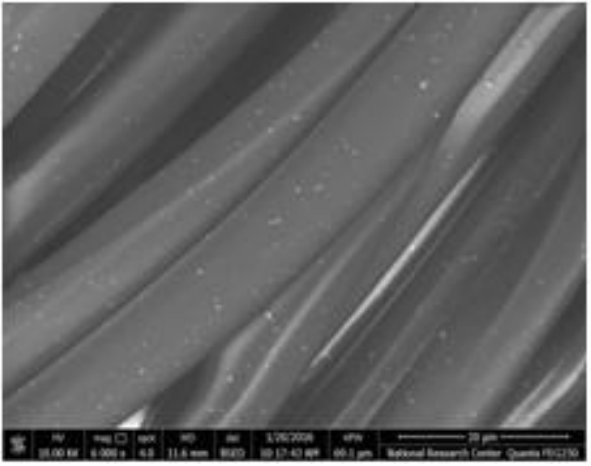

(c)

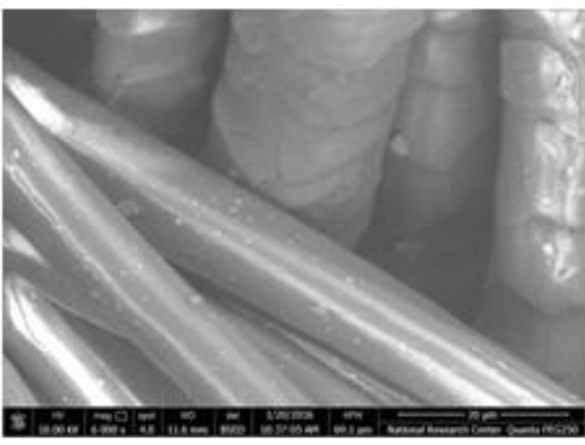

(e) fiber (Fig.6d) which shows etched surface as a result of hydrolysis of outer surface with protease enzyme. Figures (6e) and (6f) show the SEM images of wool/nylon blend fiber before and after protease treatment respectively.

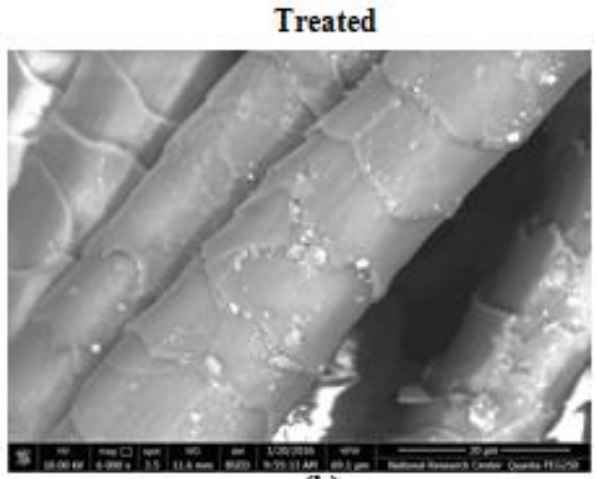

(b)

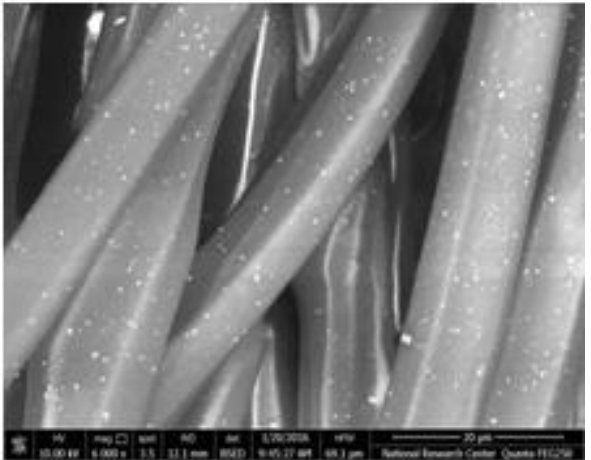

(d)

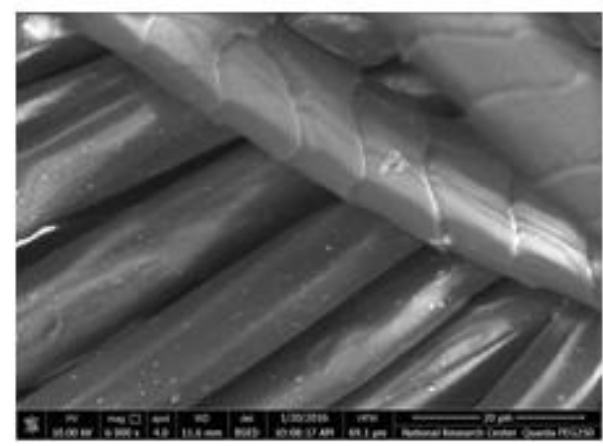

(f)

Figure 6: SEM images of (a) untreated wool, (b) treated wool, (c) untreated nylon, (d) treated nylon, (e) untreated blend and (f) treated blend.

\subsection{Wettability}

The effect of protease treatment on the wettability of wool/nylon blend fabric was determined. It was observed that the damage of the outer fibers surfaces due to hydrolysis reaction of protease resulted in an improved wettability property of the blend fabric. The wettability time of the protease treated blend fabric was decreased by about $35 \%$ compared to the untreated sample.

\subsection{Fastness Properties}

The fastness properties of wool/nylon blend, wool and nylon fabrics which were subjected to protease treatment and dyed with cutch natural dye were tested according to standard methods and the results are shown in table (4).
It is showed from table (4), that that the fastness properties of dyed fabrics to washing, perspiration ranged from very good to excellent (4-5) especially with one- bath two- stage method. The light fastness is observed to be good (4-5) for nylon and very good for both wool and blend fabrics. The overall fastness properties achieved with the two- bath method are ranging from good to very good for the fastness to washing and from very good (4) to very good- excellent (4/ 4-5) for perspiration. The light fastness is observed to be ranged from fair (3) to good (4-5) in case of using two- bath method.

In general, the fastness properties of the dyed samples may be considered as acceptable from the practical point of view. 
International Journal of Science and Research (IJSR)

ISSN (Online): 2319-7064

Index Copernicus Value (2013): 6.14 | Impact Factor (2014): 5.611

Table 4: Fastness properties of enzyme treated and dyed fabrics.

\begin{tabular}{|c|c|c|c|c|c|c|c|c|c|c|c|}
\hline \multirow{3}{*}{\multicolumn{2}{|c|}{ Method }} & \multirow{2}{*}{\multicolumn{3}{|c|}{ Fastness to washing }} & \multicolumn{6}{|c|}{ Fastness to perspiration } & \multirow{4}{*}{$\begin{array}{l}\text { Light } \\
\text { Fastness } \\
5-6\end{array}$} \\
\hline & & & & & \multicolumn{3}{|c|}{ Acidic } & \multicolumn{3}{|c|}{ Alkaline } & \\
\hline & & Alt. & $\mathrm{SC}$ & SW & Alt. & $\mathrm{SC}$ & SW & Alt. & $\mathrm{SC}$ & SW & \\
\hline \multirow{3}{*}{$\begin{array}{l}\text { One- } \\
\text { bath }\end{array}$} & $\mathrm{W}$ & $4-5$ & $4-5$ & $4-5$ & $4-5$ & $4-5$ & $4-5$ & $4-5$ & $4-5$ & $4-5$ & \\
\hline & $\mathrm{N}$ & $4-5$ & $4-5$ & $4-5$ & $4-5$ & $4-5$ & $4-5$ & $4-5$ & $4-5$ & $4-5$ & $4-5$ \\
\hline & $\mathrm{B}$ & $4-5$ & $4-5$ & $4-5$ & $4-5$ & $4-5$ & $4-5$ & $4-5$ & $4-5$ & $4-5$ & 6 \\
\hline \multirow{3}{*}{$\begin{array}{l}\text { Two- } \\
\text { bath }\end{array}$} & $\mathrm{W}$ & 4 & $3-4$ & 4 & $4-5$ & $4-5$ & $4-5$ & $4-5$ & $4-5$ & $4-5$ & $4-5$ \\
\hline & $\mathrm{N}$ & 4 & $3-4$ & 4 & $4-5$ & 4 & $4-5$ & $4-5$ & $4-5$ & $4-5$ & 4 \\
\hline & $\mathrm{B}$ & 4 & $3-4$ & 4 & $4-5$ & 4 & $4-5$ & $4-5$ & $4-5$ & $4-5$ & 3 \\
\hline
\end{tabular}

N.B.:- Alt. = Alteration or change in colour , $\mathrm{SC}=$ Staining on Cotton and $\mathrm{SW}=$ Staining on wool. - (W) refers to wool samples, $(\mathrm{N})$ refers to nylon samples and (B) refers to blend samples.

\section{Conclusion}

Wool/nylon blend fabric was treated with protease enzyme at different concentrations for $40 \mathrm{~min}$. and at fixed conditions of $\mathrm{pH}$ and temperature. Cutch natural dye was used for dyeing the enzyme treated fabric by using two different methods, namely: one- bath and two- bath method. Enzyme treatment caused to significant increase in colour strength of both wool and nylon in their blend. The twobath method gave higher K/S compared to the one- bath method. The fastness properties of dyed fabrics to washing, perspiration and light were found to range between good and very good for the two used processes. Protease treatment catalyzed the hydrolysis of amide functional groups in both nylon and wool fibres resulting in acceleration the rate and magnitude of dye penetration inside the fibres. The enzyme treatment of wool/nylon blend fabric improved the wettability as a result of surface modification of fibres.

\section{References}

[1] S. D. Wavhal and R. H. Balasubramanya, " Indian J Microbiol", 51(2):117-123, Apr-June (2011).

[2] E. Csiszar, "Textile Research Journal”, 82(19): 20302040, (2012).

[3] P. Jaruhar and JN Chakraborty, "Textile Research Journal”, 83(13): 1345-1355, (2013).

[4] L. Ammayappan,"Journal of Textile and Apparel, Technology and management", Vol. (8), Issue (3): 1-12, (2013).

[5] L. Ammayappan, "Asian Journal of Textile", 3(1): 1528, (2013).

[6] S. H. Lee and W. S. Song, "Textile Research Journal”, 83(3): 229-237, (2013).

[7] H. S. El-khateeb," International Design Journal, no.12, p.143-152, (2012).

[8] E.S. Pooja and N. Fatima, "Environment and Ecology Research", 2(8): 301-310, (2014).

[9] S. Dixit and S. Jahan," Universal Journal of Environmental Research and Technology", Volume 4, Issue 2: 72-81, (2014).

[10]R. Arau' Jo, M. Casal, \& A. Cavaco-Paulo," Biocatalysis and Biotransformation", September_October; 26(5): 332-349, (2008).

[11]D. M. El-Zeer and A. A. Salem, "International Journal of Innovation and Applied Studies", Vol. (7) No. (1), July, 159-173, (2014).

[12] S. Hooda, K. Khambra, N. Yadav and V. K. Sikka, "American International Journal of Research in Formal,
Applied \& Natural Sciences”, 3(1), June-August, 66-69, (2013).

[13] M. P. Gashti, R. Assefipour, A. Kiumarsi \& M. P. Gashti," Preparative Biochemistry and Biotechnology", Vol. 43, Issue 8, 798-814, (2013).

[14] M. Parvinzadeh, R. Assefipour and A. Kiumarsi, "Polymer Degradation and Stability". 94: 1197- 1205, (2009).

[15] S. Saxena and A. S. M. Raja, "Natural Dyes: Sources, Chemistry, Application and Sustainability Issues", Springer Publisher, 37-80, (2014).

[16]A. K. Samanta and A. Konar, "Natural Dyes", InTech Publisher, Rijeka- Croatia, p.29, (2011).

[17] M. I. Khan, A. Ahmad, S. A. Khan, M. Yusuf, M. Shahid,N. Manzoor, F. Mohammad, "Journal of Cleaner Production”, 19: 1385-1394, (2011).

[18]G. F. Colbrie; S. Heumann, G. Guebitz, "2nd International Conference of Textile Research Division", NRC, Cairo, Egypt, April 11-13, (2005).

[19] T.Z. Tzanov, S. Costa, G. Gubitz, and A. CavacoPaulo, "Color. Techn.", Vol. 117, 28-32, (2001 b).

[20]K. Blus and J. Bemska, "AUTEX Research Journal”, Vol. 10, No3, September, 64-68, (2010).

[21] Y. Nemoto and H. Funahashi, "Ind. Eng. Chem. Prod. Res. Dev.", 19 (2), 136-142, (1980).

[22] S. Chandravanshi and S. K. Upadhyay, "Coloration Technology", Volume 128, Number 4, August, 300305(2012).

[23] S. Chandravanshi and S. K. Upadhyay,"Journal of Chemistry", Volume 2013, (2013).

[24] J. Liu, J, Shi, J. Li and X. Yuan, "Enzyme Microb Technol”, Sep 10; 49 (4): 360-365, (2011). 